\title{
Organoleptic Quality of Salted Quail Eggs Using Boiled Salt From Brebes
}

\author{
Muhamad Hasdar*, Yunika Purwanti, dan Nurwati \\ Food Science and Technology, Muhadi Setiabudi University, Brebes, Indonesia \\ Corresponding author: Muhamad Hasdar \\ *email : hasdarmuhammad@umus.ac.id
}

\begin{abstract}
Salted eggs are one of the popular products and are liked by the people of Indonesia. Processing salted quail eggs is an effort for preservation, in addition to improving the taste of quail eggs This study aims to determine the organoleptic quality of quail eggs salted with fine boiled salt with a concentration of $20 \%(\mathrm{w} / \mathrm{w})$ and $30 \%(\mathrm{w} / \mathrm{w})$. The incubation time for the salting process is 4 days. organoleptic test with 60 untrained panellists. Yolk colour quality produces a slightly yellow colour $(\mathrm{p}>0.05)$. The aroma of salted quail eggs is slightly fishy $(p>0.05)$. Taste quality has a difference $(p<0.05)$ where the $20 \%$ salt concentration treatment produces a bit less salty, while the $30 \%$ salt concentration treatment produces a slightly salty taste. The tasting test did not have a difference between treatments $(\mathrm{P}>0.05)$ which produced unsubstantiated eggs, and the panellists' organoleptic test on average resulted in a preference for the $30 \%$ salt concentration treatment.
\end{abstract}

Keyword : Eggs, quail, salted, organoleptic test, boiled salt

\section{Introduction}

Quail (coturnix coturnix) japonica is one of poultry commodities that have an important role and prospect to produce eggs (Patanggara et al., 2019). Quail eggs have a high nutritional value and are almost the same as eggs on the market. The nutritional value of quail eggs, which is $13.6 \%$, is greater than the protein value of chicken eggs, which is $12.8 \%$. Quail eggs are food that is easily damaged if stored for more than one month at room temperature. This high protein value must be preserved by preserving it. One of the preservation of quail eggs is by salting. The salting process will extend the shelf life, get rid of the fishy smell and create a distinctive taste. Eggs stored for more than 2 weeks in an open space will experience a decrease in quality and if stored for more than 1 month, the contents in the eggs will be damaged. The first damage is in the form of natural damage such as a break or crack. Egg damage also occurs due to the entry of microorganisms into the eggs.

Salted eggs are one of the products that the public likes. The principle of making salted eggs is the ionization process of salt which then diffuses into the eggs through the pores of the shells. The purpose of making salted eggs is as an effort for preservation, but also to improve the taste of the eggs. The process of salting eggs, in general, uses salt with the Soaking method with salt solution or wrapped in a mixture of salt dough, rubbing ash, and water after that it is cleaned with running water until clean and then boiled. The quality of salt used will affect the quality of the eggs produced, both the 
crystal size of salt and the amount of concentration used during salting (Wibawanti et al., 2015). While the concentration that is too high will cause the size of the salt crystals into the egg to be inhibited, if the crystal size is too large, the salty taste level is high, making the salting process faster (Ariviani et al., 2018).

Quail eggs have eggshells that are not as thick as consumption eggs such as eggs from laying hens so that the diffusion process or penetration of salt into the eggs will be easier. This research will utilize salt from the area / local salt, salt used is salt from Kaliwlingi village, Wanasari district, Brebes district.

\section{Materials and Methods}

This study used 2 treatments, namely treatment with the salt concentration used, namely $20 \%(\mathrm{w} / \mathrm{w})$, and $30 \%(\mathrm{w} / \mathrm{w})$, the commodity of salt used was boiled salt produced in the village of Kalpool, Brebes. The type of quail eggs used in this study is a type of quail eggs from the Coturnix-Coturnix Japanica quail species. The number of quail eggs used was 30 eggs for 1 treatment of the salting period and 1 concentration of salt with a total number of 60 eggs.

\section{The Salting Process}

Salting with a salt paste solution. The salt paste solution made in this study uses the same salt concentration, namely $20 \%(\mathrm{w} / \mathrm{w})$ and $30 \%(\mathrm{w} / \mathrm{w})$ of the weight of the salt paste dough, where the salt paste solution has a composition of boiled salt, brick ash, husk ash, and water. The effect of salt on the eggs of salt paste dough has a sedative property, causing the dissolved salt content in the paste to drop down like a salt solution in water which saturates and settles to the bottom of the solution and this makes quail eggs incubated in a salt solution or solution salt paste has a salty taste that is not compact (Borsato et al., 2012). The salting process follows the flow chart below:

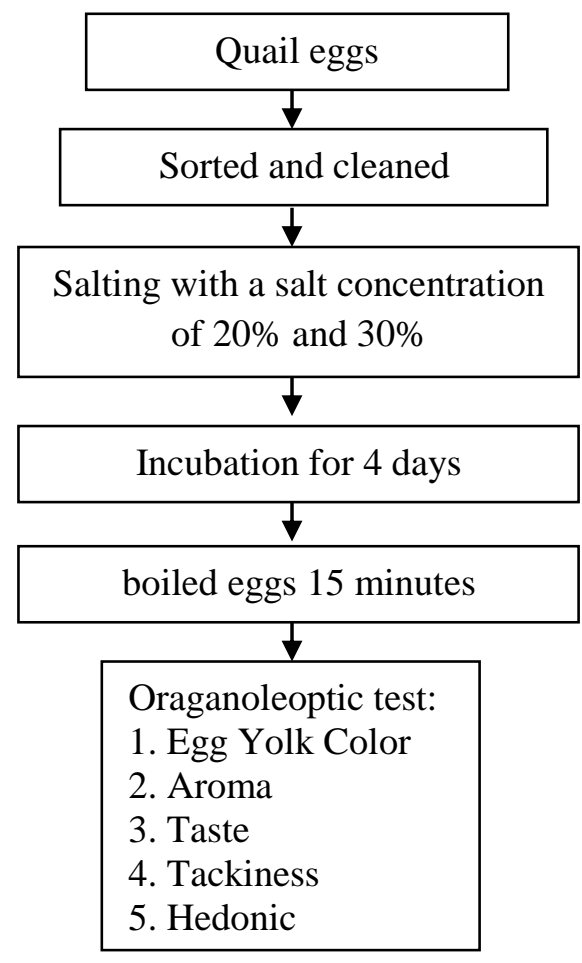


Figure 1. Flowchart of Making Salted Quail Eggs

\section{Data analysis}

The data obtained were analyzed using Chi-Square test analysis. The basis for decision making in chi-square can see the output value of the "Chi-Square Test" as a result of data processing with SPSS. Decision making is guided by two things, namely comparing the Asymp values. Sig with a critical limit of 0.05 or by comparing the calculated chi-square value with the chi-square table (Franke et al., 2012).

\section{Research Parameters}

The parameters of this study were using the organoleptic test which consisted of egg yolk colour, egg aroma, egg taste, egg baggage, and organoleptic test. Organoleptic test using 6 scores in the assessment of each variable (Tharukliling and Fanani, 2018).

1. Egg yolk colour

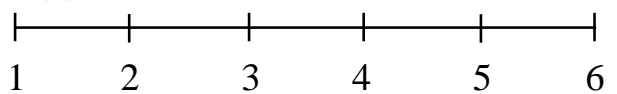

Color:

1. A little yellow

2. Yellow

3. Yellowish Orange

4. Somewhat Orange

5. Orange

6. Very Orange

2. Egg aroma

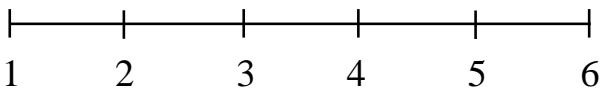

Aroma:

1. Very fishy

2. Fishy

3. A little fishy

4. Somewhat fishy

5. Not fishy

6. Very fishy

3. Egg taste

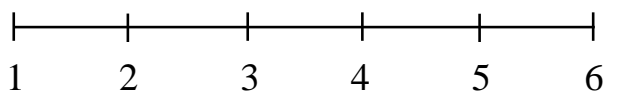

Taste:

1. Not very salty

2. Not salty

3. Somewhat salty

4. Slightly salty

5. Salty

6. Very salty 
4. Egg granular

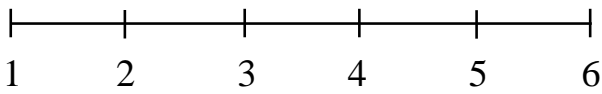
granular:
1 . Not very granular
2. Not granular
3. Somewhat granular
4. Slightly granular
5. Granular
6. Very granular

5. Organoleptic test

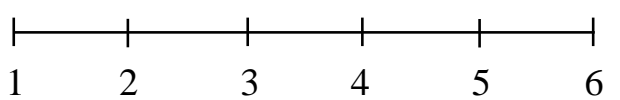

Hedonic test :

1. Very disliked

2. Dislike

3. Somewhat like it

4. Like

5. Really like

6. Very very much like

\section{Results and Discussion}

\section{a. Color Organoleptic Test}

Colour is the first sensory that can be seen directly by panellists. determining the quality of food ingredients generally depends on the colour they have, the colour that does not deviate from the colour which should give the impression of a separate assessment by the panellists. The data from the calculation of the colour of salted quail eggs can be seen in Table 1.

Table 1. Average Organoleptic Test for Yolk Color of Salted Quail Eggs

\begin{tabular}{cccc}
\hline Salt Concentration & Incubation Time & Favorite Score & Criteria \\
\hline $20 \%$ & 4 days & $1,40 \mathrm{a}$ & A little yellow \\
$30 \%$ & 4 days & $1,83 \mathrm{a}$ & A little yellow \\
\hline
\end{tabular}

Note: superscript ${ }^{\mathrm{abc}}$ with the same letter is not significantly different $(\mathrm{P}>0.05)$

Based on the results of statistical tests in Table1, there is no significant difference (P> 0.05 ) in the colour of salted quail eggs between the concentration of $20 \%$ and $30 \%$. This is due to the ineffective granulation process of the quail egg yolk protein by salt. The discolouration of egg yolk due to the salting process is caused by the effectiveness of salt in forming egg lipoprotein granules. The average value of the colour organoleptic test of 30 panellists was 1.40 and 1.83 with the criteria slightly yellow to yellow. This shows that the colour of salted quail egg yolk is not as good as salted duck egg yolk. because the yolk is located in the middle so it is difficult for salt to enter the egg yolk. It can also be caused by the very high fat in the yolk which causes the penetration of the 
salt solution into the egg yolk not maximally or is inhibited (Wang, 2017). While the egg white itself is located on the outside so that salt is easier to enter (Nurliyani et al., 2015).

\section{b. Aroma Organoleptic Test}

The aroma assessment in the organoleptic test aims to determine consumer acceptance of food. The aroma is determined not only by one component but by several components that give off a distinctive odour. The aroma received by the nose and brain is more so that it produces 6 salted egg scents, namely; 1) Very fishy, 2) Fishy, 3) A little fishy, 4) A little fishy, 5) Not fishy, 6) Not very fishy. Organoleptic test results of quail salted egg yolk aroma of this study are shown in table 2 . below

Table 2. Average Organoleptic Test of Salted Quail Egg Aroma

\begin{tabular}{cccc}
\hline Salt Concentration & Incubation Time & Favorite Score & Criteria \\
\hline $20 \%$ & 4 days & $3,06^{\mathrm{a}}$ & A little fishy \\
$30 \%$ & 4 days & $3,20^{\mathrm{a}}$ & A little fishy \\
\hline
\end{tabular}

Note: superscript ${ }^{\mathrm{abc}}$ with the same letter is not significantly different $(\mathrm{P}>0.05)$

Based on the results of the statistical test in table 5, it showed that there was no significant difference $(\mathrm{P}>0.05)$ in the results of the organoleptic aroma test between $20 \%$ and $30 \%$ salt concentrations with 4 days of salting time. This was because the difference in salt levels in egg whites could not be identified by the panellists through sensory testing. This is presumably because each panellist can express a personal subjective attitude towards the organoleptic properties of the object.

The average organoleptic aroma test of this study showed scores of 3.06 and 3.20 with rather fishy criteria. This is due to the raw material that is quail eggs. The fishy aroma of quail eggs is strongly influenced by the feed given to quail while in cattle. If quail eggs are given a lot of fishy-smelling feed for example from fish bones will produce quail eggs that smell fishy. In the study, quail eggs are not derived from farms that are given fishbone feed so that the salted quail eggs do not smell salty like salted duck eggs (Xu et al., 2017).

\section{c. Taste Organoleptic Test}

Taste is an important factor in food products. The taste of salted eggs generally tastes salty, according to the level of salt applied in making salted eggs and the time for curing. The results of the organoleptic test of salted quail eggs in this study are shown in Table 3 below.

Table 3. Average Organoleptic Test of Salted Quail Egg Taste

\begin{tabular}{cccc}
\hline Salt Concentration & Incubation Time & Favorite Score & Criteria \\
\hline $20 \%$ & 4 days & $3,16^{\mathrm{a}}$ & Somewhat Salty \\
$30 \%$ & 4 days & $4,23^{\mathrm{b}}$ & Slightly salty \\
\hline
\end{tabular}

Note: superscript ${ }^{a b c}$ with the same letter is not significantly different $(\mathrm{P}>0.05)$ 
Based on table 3 , shows that $30 \%$ of salt concentration has an impact on the salty taste of salted quail eggs. The increase in the salty taste score is directly proportional to the addition of salt concentration, this indicates that the penetration ability of salt crystal molecules takes time to make lipoprotein granules from quail eggs into coarse particles due to salt penetration. This is due to the characteristics of the same raw material, namely quail eggs from the same breeders so that the protein content of quail eggs is relatively the same (Tan et al., 2016). On the other hand, the panellists' subjective assessment of saltiness greatly influenced the resulting statistical results (Nur'aini et al., 2020).

\section{d. Granular Organoleptic Test}

Salted egg granular can occur because the ability of salt to bind water has a greater affinity than protein, causing stronger bonds between molecules (Gómez et al., 2020). The strong bonds cause the proteins to clump together (Xianglei et al., 2013). Protein coagulation in egg yolk causes a salty and gritty taste. The granular taste of the yolk is also influenced by the amount of oil released, the gel strength of the yolk and the egg yolk granule diameter (Kaewmanee et al., 2011). The higher the value of the three quality criteria, the higher the egg yolk granular taste is. The results of the sensory test for the level of preference for granular parameters of quail salted eggs in the yolk can be seen in Table 4 below.

Table 4. Average Granular Organoleptic Test a Salted Quail Eggs

\begin{tabular}{cccc}
\hline Salt Concentration & Incubation Time & Favorite Score & Criteria \\
\hline $20 \%$ & 4 days & $3,00^{\mathrm{a}}$ & Somewhat granular \\
$30 \%$ & 4 days & $3,46^{\mathrm{a}}$ & Somewhat granular \\
\hline
\end{tabular}

Note: superscript ${ }^{\mathrm{abc}}$ with the same letter is not significantly different $(\mathrm{P}>0.05)$

Based on the results of statistical tests there was a difference ( $>>0.05)$ granular between quail eggs salted with different concentration. Quail eggs soaked in 30\% salt produced consistent granularity with slightly granular criteria. However, statistically, the highest granular yields were salted whole eggs soaked in $30 \%$ salt for 4 days of immersion resulting in an average organoleptic test score of 3.46. This phenomenon also occurs in the granular of salted quail eggs with a treatment of $20 \%$ with a soaking time of 4 days which results in an average organoleptic test score of 3.00. This incident occurred as a result of subjective granular judgments by the panellists. Subjective judgments by consumers are caused by differences in understanding of the granular parameters of each consumer, including consumer tastes (Sousa et al., 2007).

\section{E. Salted Quail Eggs Favorite Test}

Assessment or preference test is the most primitive way of assessment. In this test, the emphasis is placed on the ability of the senses to give impressions or responses that can be analyzed or differentiated based on the type of impression (Sumekar and AlBaarri, 2020). These capabilities include the ability to detect, recognize, discriminate, 
compare (scaling) and the ability to express likes or dislikes (Wang et al., 2017). The consumer's favourite results of salted quail eggs can be seen in Table 5 below.

Table 5. Average Salted Quail Egg Taste Test

\begin{tabular}{cccc}
\hline Salt Concentration & Incubation Time & Favorite Score & Criteria \\
\hline $20 \%$ & 4 days & $3,26^{\mathrm{a}}$ & Somewhat Like \\
$30 \%$ & 4 days & $3,86^{\mathrm{b}}$ & Like \\
\hline
\end{tabular}

Note: superscript ${ }^{\mathrm{abc}}$ with the same letter is not significantly different $(\mathrm{P}>0.05)$

The results of statistical analysis showed that the salting which was carried out by various methods had a significant or nonsignificant effect $(\mathrm{P}<0.05)$ on the preference for salted quail eggs. This shows that quail eggs salted by various methods of salting do not affect the preference for salted quail eggs. Based on the average organoleptic test score of preference for panellists' assessment of the treatment of salting quail eggs with $30 \%$ salt concentration, there was an increase in the average score of the panellists' favourite score 3.86. The increase in the panellists' preference score was influenced by the subjective nature of the panellists regarding the preference for salted quail eggs. Panellists will usually compare it to salted duck eggs because panellists consume salted duck eggs more often (Novia and Juliyarsi, 2019). In the liking test, the panellists were asked for their responses about their likes or dislikes and also stated their level of preference, which is always related to the existence of the product and the acceptance of the product (Goswami et al., 2013).

\section{Conclusion}

Organoleptic quality of salted quail eggs based on differences in salt concentration showed no difference $(\mathrm{P}>0.05)$ in the quality of egg yolk color, aroma, taste and preferences but did show differences in the quality of tasting ( $\mathrm{P}<0.005)$. The quality of salted quail eggs is good according to the results of the organoleptic test, namely at a concentration of $30 \%$ at 4 days salting duration with an average score of 3.46 .

\section{Acknowledgement}

Thanks to LPPM Muhadi Setiabudi University for providing funding for this research so that it goes well.

\section{References}

Ariviani, S., Fitriasih, N.H., Ishartini, D., 2018. Development of low sodium salted eggs and its antioxidant potential. J. Gizi dan Diet. Indones. (Indonesian J. Nutr. Diet. 5, 51.

Borsato, D., Moreira, M.B., Moreira, I., Pina, M.V.R., Silva, R.S. dos S.F. da, Bona, E., 2012. Saline distribution during multicomponent salting in pre-cooked quail eggs. Food Sci. Technol. 32, 281-288.

Franke, T.M., Ho, T., Christie, C.A., 2012. The Chi-Square Test: Often Used and More Often Misinterpreted. Am. J. Eval. 33, 448-458. 
Gómez, I., Janardhanan, R., Ibañez, F.C., Beriain, M.J., 2020. The effects of processing and preservation technologies on meat quality: Sensory and nutritional aspects. Foods 9, 1-30.

Goswami, M., Pathak, V., Singh, V., Nayak, N., Upadhyay, S., 2013. Effect of natural preservatives on sensory and microbiological properties of quail egg pakoda. Indian J. Poult. Sci. 48, 313-317.

Kaewmanee, T., Benjakul, S., Visessanguan, W., 2011. Effects of Salting Processes and Time on the Chemical Composition, Textural Properties, and Microstructure of Cooked Duck Egg. J. Food Sci. 76.

Novia, D., Juliyarsi, I., 2019. Quality characteristics of salted egg soaked with Aloe vera solution. Int. J. Adv. Sci. Eng. Inf. Technol. 9, 434-440.

Nur'aini, Suningsih, N., Hakim, M., 2020. Organoleptic Test of Salted Eggs with Addition of Herbal Plants. Indones. J. Agric. Res. 3, 171-178.

Nurliyani, N., Hartawan, A., Nugroho, Y.A., Indratiningsih, I., 2015. The Characteristics of Salted Chicken and Duck Egg by Using Traditional Roasting 738-742.

Patanggara, E. U. H., V. D. Yunianto, B. Sukamto, and L. Krismiyanto. 2019. The use of calcium in quails during egg hatching phase by adding yacon leaf powder (Smallantus sonchifolius). Bantara J. Anim. Sci. 1(1) : 21-27.

Sousa, R. de C.S., Coimbra, J.S.R., Garcia Rojas, E.E., Minim, L.A., Oliveira, F.C., Minim, V.P.R., 2007. Effect of $\mathrm{pH}$ and salt concentration on the solubility and density of egg yolk and plasma egg yolk. LWT - Food Sci. Technol. 40, 12531258.

Sumekar, W., Al-Baarri, A.N., 2020. Study in Agroindustry of Salted Egg: Length of Salting Process and Marketing Reach Aspects. J. Appl. Food Technol. 7, 25-28.

Tan, T.C., Phatthanawiboon, T., Mat Easa, A., 2016. Quality, Textural, and Sensory Properties of Yellow Alkaline Noodles Formulated with Salted Duck Egg White. J. Food Qual. 39, 342-350.

Tharukliling, S., Fanani, Z., 2018. Effect of Use Different Eggs with Different Techniques of Salted Eggs on the level of Consumer Preference. J. Dev. Res. 2, 15.

Wang, T.H., 2017. Salting yolks directly using fresh duck egg yolks with salt and maltodextrin. J. Poult. Sci. 54, 97-102.

Wang, Z.F., Dai, C., Wang, T.Y., 2017. A simple method to evaluate oil in salted egg. Int. J. Food Prop. 20, 1816-1822.

Wibawanti, J.M.., Meihu, M., Hintono, A., Pramono, Y.B., 2015. The Characteristcs Of Salted Egg In The Presence Of Liquid Smoke. J. Appl. Food Technol. 3, 193-198.

Xianglei, T., Meijuan, R., Qin, Z., Guangpeng, L., 2013. Study on the granulation texture of salty yolk. Adv. J. Food Sci. Technol. 5, 613-618.

Xu, L., Zhao, Y., Xu, M., Yao, Y., Nie, X., Du, H., Tu, Y. gang, 2017. Effects of salting treatment on the physicochemical properties, textural properties, and microstructures of duck eggs. PLoS One 12, 1-17. 